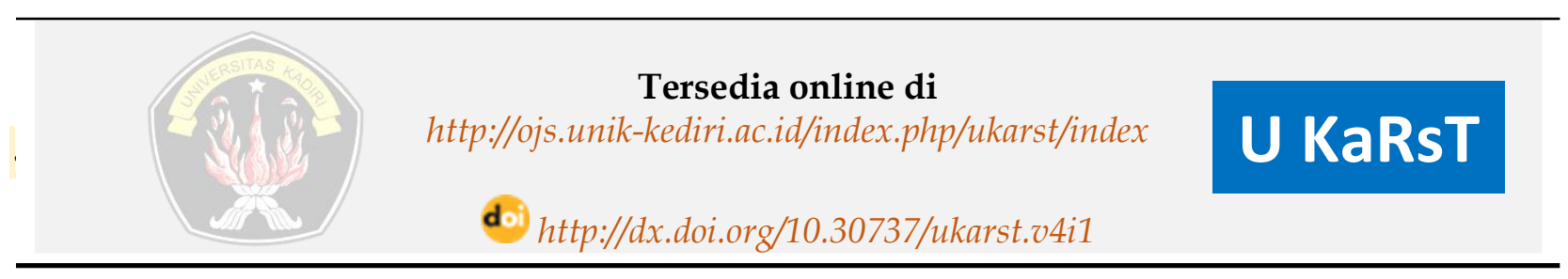

\title{
Analisa Kekuatan Struktur Bambu Pada Pembangunan Entry Building Green School Ubud
}

\author{
I. N. R. D. Putra ${ }^{1}$, I. N. Sinarta ${ }^{2}$, I. K. Y. Bagiarta ${ }^{3}$. \\ ${ }^{1,2,3}$ Fakultas Teknik dan Perencanaan Universitas Warmadewa, Bali. \\ email : arianadamara81@gmail.com
}

\begin{tabular}{ll} 
A R T I C L E I N F O \\
\hline $\begin{array}{l}\text { Article History : } \\
\text { Artikel masuk }\end{array}$ & $: 25-02-2020$ \\
Artikel revisi & $: 16-03-2020$ \\
Artikel diterima & $: 18-03-2020$ \\
\hline
\end{tabular}

Keywords:

Green Building, Bamboo,

Sap2000, Structure

Style IEEE dalam mensitasi artikel ini: [1]

I. G. L. B. Eratodi and A. Awaludin, "Bending Capacity of Non-prismatic LVL Beams Paraserianthes Falcataria," Procedia Eng., vol. 171, pp. 1362-1369, 2017.

\begin{abstract}
A B S T R A C T
Bamboo has $1.000-4.000 \mathrm{~kg} / \mathrm{cm} 2$ tensile strength, so it becomes a substitute for reinforced concrete steel reinforcement. Makes bamboo has the potential to continue to be developed as a construction material not only for simple buildings but for more complex buildings. The elastic nature of bamboo, the bamboo structure has a high resistance to both wind and earthquake, where the MOE (Modulus of Elasticity) of $178.758 \mathrm{~kg} / \mathrm{cm} 2$, MOR (Modulus of Rupture) of $886 \mathrm{~kg} / \mathrm{cm} 2$, and compressive strength of $347 \mathrm{~kg}$ of fiber parallel on cm2. Analysis using SNI 1727-2013 for loading, SNI 1726-2012 for earthquake loading. Modeling and analysis of internal forces on structures using the software Sap2000 ver.15. The results of the upper structure of the dimensions of the bamboo frame diameter $120 \mathrm{~mm}$ and bamboo rafts diameter $80 \mathrm{~mm}$. The superstructure on the bamboo column diameter $150 \mathrm{~mm}$ and bamboo beam diameter $150 \mathrm{~mm}$. Planning bamboo plates with diameter $80 \mathrm{~mm}$. Substructure with concrete material the size of the footing $0.8 \mathrm{~m} \times 0.8 \mathrm{~m}$ and $1.2 \mathrm{~m} \times 1.2 \mathrm{~m}$ for anchor planning using bolt dimensions $12.7 \mathrm{~mm}$ with the number of bolts as many as two pieces.
\end{abstract}

\section{A B S T R A K}

Bambu memiliki kekuatan Tarik sebesar 1.000-4.000 kg/cm2 atau setara dengan besi baja kualitas sedang sehingga dapat menjadi pengganti tulangan baja beton bertulang. Hal ini membuat bambu memiliki potensi untuk terus dikembangkan sebagai material konstruksi bukan hanya untuk bangunan yang sederhana namun untuk bangunan yang lebih kompleks. Sifat bambu yang elastis, struktur bambu mempunyai ketahanan yang tinggi baik terhadap angin maupun gempa, dimana MOE (Modulus of Elasticity) sebesar 178,758 kg/cm ${ }^{2}$, MOR (Modulus of Rupture) sebesar 886 $\mathrm{kg} / \mathrm{cm}^{2}$, dan kuat tekan sejajar serat sebesar $347 \mathrm{~kg} / \mathrm{cm}^{2}$. Analisa dengan menggunakan SNI 1727-2013 untuk pembebanan, SNI 1726-2012 untuk pembebanan gempa. Pemodelan dan analisa gaya dalam pada struktur dengan bentuan software Sap2000 ver.15. Hasil upper struktur dimensi kuda-kuda bambu $120 \mathrm{~mm}$ diameter baut $15 \mathrm{~mm}$ sejumlah 1, usuk bambu diameter $80 \mathrm{~mm}$, baut $8 \mathrm{~mm}$ berjumlah 1 buah. Super struktur pada kolom bambu berdiameter $150 \mathrm{~mm}$ dan balok bambu dengan diameter $150 \mathrm{~mm}$ 
menggunakan Perencanaan plat bambu dengan diameter $80 \mathrm{~mm}$. Sub struktur dengan bahan beton ukuran pondasi telapak $0,8 \mathrm{~m} \mathrm{x}$ $0,8 \mathrm{~m}$ dan $1,2 \mathrm{~m} \times 1,2 \mathrm{~m}$ untuk perencanaan angkur menggunakan diemensi baut $12,7 \mathrm{~mm}$ dengan jumlah baut yaitu sebanyak 2 buah.

\section{Pendahuluan}

Konstruksi membutuhkan stabilitas khusus terutama jika terdapat dua atau lebih material yang harus disambungkan atau digabung, jika material sejenis seperti halnya bamboo tidak bisa disambung sempurna atau monolit, maka perilaku sambungan terjepit penuh tidak terpenuhi[1]. Penggunaan bambu biasanya digunakan sebagai bahan perkuatan pada tanah lunak seperti cerucuk bambu sehingga mampu menahan penurunan dan mengurangi konsolidasi tanah lunak [2] [3] dan juga digunakan sebagai perancah/bekisting, reng atap dan furniture. Pengujian oleh Yap (1967) bambu memiliki kekuatan tarik yang tinggi yaitu sebesar $1.000-4.000 \mathrm{~kg} / \mathrm{cm}^{2}$ atau setara dengan besi baja kualitas sedang [4]. Sementara itu ketersediaan bambu cukup banyak dan mudah didapat di daerah tropis maupun subtropics di dunia, harganya relatif murah karena dalam beberapa bulan bambu sudah dapat tumbuh dengan baik. Bambu tua dalam beberapa tahun dapat mencapai ketahanan mekanis maksimum.

Bambu untuk bahan bangunan dapat digunakan pada kondisi tanah basah dan kering [5], pada kondisi tanah basah bambu dapat dimanfaatkan sebagai pondasi ceroak [6][7]. Bambu sebagai bahan bangunan berbentuk bulat digunakan untuk kolom [8], balok dan plat sedangkan dalam bentuk anyaman untuk bahan dinding, langit-langit, daun pintu dan jendela [9]. Sambungan bambu dapat dilakukan dengan sistem pasak tali atau ijuk dilakukan dengan sistem pasak tali atau ijuk. Berdasarkan hasil penelitian dan penggunaan material bambu tersebut, maka akan dilakukan kajian untuk analisa kekuatan konstruksi berbahan bambu pada sistem struktur atas (Upperstructure), struktur utama (Superstructure) dan struktur bawah (Substructure) pada konstruksi Entry Building Green School Ubud.

\section{Tinjauan Pustaka}

\subsection{Propertis Bambu}

Kekuatan mekanik seperti kuat tekan, kuat tarik dan kuat lentur bambu cenderung mengalami peningkatan dari posisi pangkal ke ujung. Adanya perbedaaan kekuatan mekanik pada posisi pangkal, tengah dan ujung selain disebabkan oleh adanya perbedaan kadar air juga lebih disebabkan karena adanya perbedaan prosentase kulit pada tampang yang ditinjau 
[10]. Kekuatan bambu bagian luar lebih besar dari dua kali kekuatan bambu bagian dalam, dengan demikian bambu, tebal kulit bambu cenderung sama rata, tetapi pada posisi ujung bambunya tipis, sehingga prosentase kulit naik [11].

\section{Kuat Tarik.}

Pohon bambu sebagai salah satu tumbuhan berakar serabut digunakan juga sebagai penahan erosi pada tebing-tebing rendah sungai, karena akar bamboo memiliki kuat Tarik yang tinggi untuk mengikat tanah di sekelilingnya sehingga tidak mudah terkikis atau menjaga kestabilan tanah [12] [13]. Bambu mempunyai kekuatan cukup tinggi, kuat tariknya dapat disejajarkan dengan baja. Bambu berbentuk pipa sehingga momen kelembabannya tinggi, oleh karena itu bambu cukup baik untuk memikul momen lentur. Berdasarkan hasil penelitian yang dilakukan oleh Haris (2008) yang menggunakan bambu petung sebagai bahan penelitian untuk mengetahui sifat fisis dan mekanis bambu maka pada hasil akhir didapatkan bahwa nilai Modulus of Elasticity (MOE) sebesar $178.758 \mathrm{~kg} / \mathrm{cm}^{2}$, nilai Modulus of Rupture (MOR) sebesar $886 \mathrm{~kg} / \mathrm{cm}^{2}$, dan kuat tekan sejajar serat sebesar $347 \mathrm{~kg} / \mathrm{cm}^{2}$ [4]. Frick (2004) menjelaskan bahwa kuat tarik yang digunakan sebesar 299,796 kg/ $\mathrm{cm}^{2}$, kuat geser sebesar $24,983 \mathrm{~kg} / \mathrm{cm}^{2}$ dan kuat lentur sebesar $99,932 \mathrm{~kg} / \mathrm{cm}^{2}$ [14]. Sifat bambu yang elastis menyebabkan penggunaan struktur bambu mempunyai ketahanan tinggi sangat baik dalam menahan beban angin maupun beban gempa dan penggunaan material bamboo juga digunakan dalam usaha perkuatan lereng karena akibat gaya Tarik yang tinggi sehingga mampu menahan beban tanah dan air system metode bioengineering dalam usaha mengurangi ancaman Gerakan tanah pada batuan vulkanik [15].

Membutuhkan lebih sedikit energi untuk produksi. Bambu sangat efisien dalam menyerap karbon dioksida dan berkontribusi terhadap pengurangan efek rumah kaca maka dipilihlah konstruksi bambu oleh penulis sebagai material utama [16]. [17] Morisco (1996) membandingkan kuat Tarik bambu ori dan petung dengan baja struktur bertegangan leleh $2400 \mathrm{~kg} / \mathrm{cm}^{2}$, dilaporkan bahwa kuat tarik dari struktur kulit bamboo ori cukup tinggi yaitu hampir mencapai $5000 \mathrm{~kg} / \mathrm{cm}^{2}$ atau sekitar dua kali tegangan leleh baja [19] [18]. Spesimen dari bambu petung kuat tarik rata-ratanya juga lebih tinggi dari tegangan leleh baja, hanya satu spesimen saja yang kuat tariknya dibawah tegangan leleh baja, seperti terlihat pada

\section{Gambar 1.}




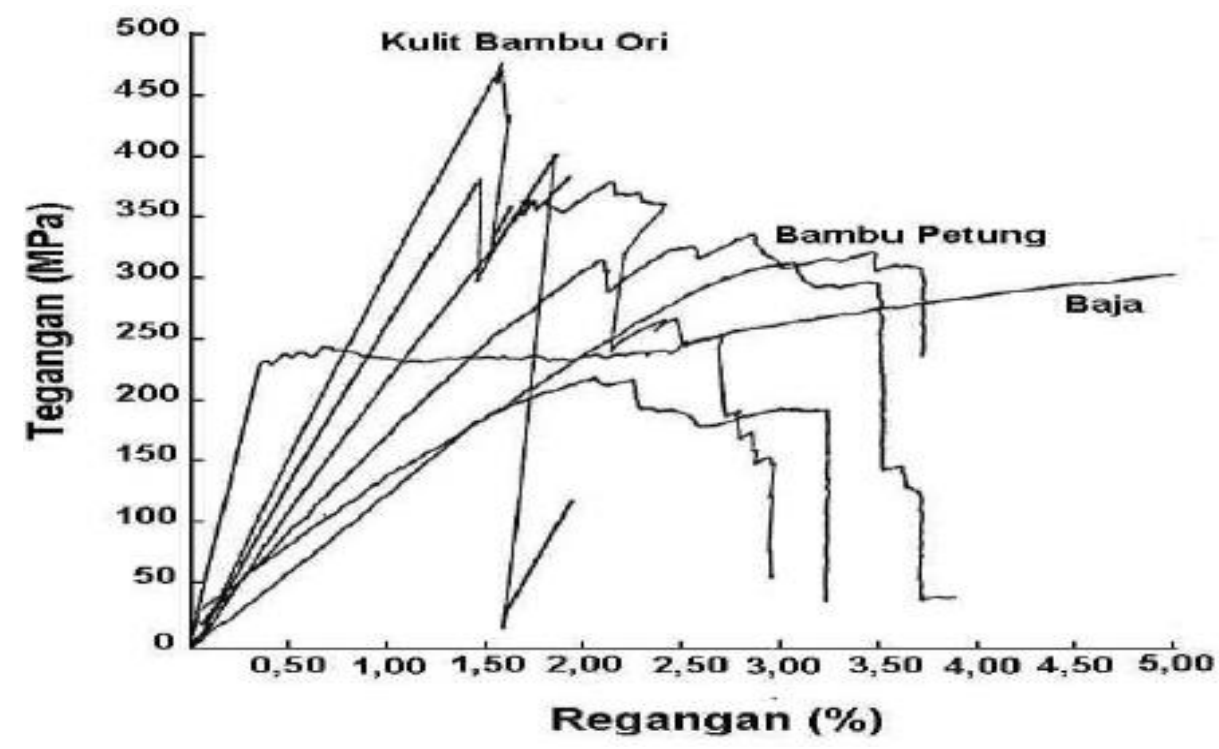

Sumber: Morisco (1996).

Gambar 1. Diagram Tegangan-Regangan Bambu dan Baja.

Kuat tarik sambungan meningkat seiring dengan meningkatnya panjang jarak ujung. Kuat tarik maksimum yang dihasilkan pada variasi jarak ujung $50 \mathrm{~mm}, 60 \mathrm{~mm}$ dan seterusnya dan persentase kenaikan kenaikan berkisar sebesar $6 \%, 17 \%, 19 \%$, dan $21 \%$ [20].

\section{Kuat Tekan Bambu.}

Tekan bambu adalah kekuatan bambu untuk menahan gaya aksial akibat adanya beban titik ataupun beban merata [21], apabila gaya tekan yang terjadi searah dengan sejejar serat bambu maka bambu akan terjadi bahaya tekuk seperti pada Gambar 2. sedangkan apabila gaya tekan yang terjadi tegak lurus dengan arah serat maka bambu akan menjadi retak. Kekuatan bambu untuk menahan gaya tekan tergantung pada bagian ruas dan bagian antar ruas batang bambu [22].

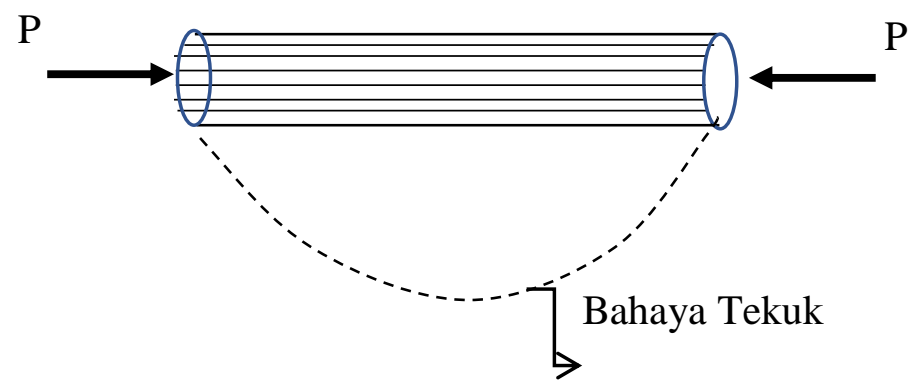

Sumber : Eratody (2017).

Gambar 2. Batang Bambu Menerima Gaya Tekan Sejajar Serat. 


\section{Kuat Geser Bambu.}

Menurut Eratodi (2017) kemampuan bambu untuk menahan gaya - gaya yang membuat suatu bagian bambu bergeser dari bagian lain di dekatnya disebut dengan kuat geser. Kuat geser bambu tergantung pada ketebalan dinding batang bambu seperti pada Gambar 3. Bagian batang tanpa ruas memiliki kekuatan terhadap gaya geser 50\% lebih tinggi dari pada batang bambu yang beruas [23].

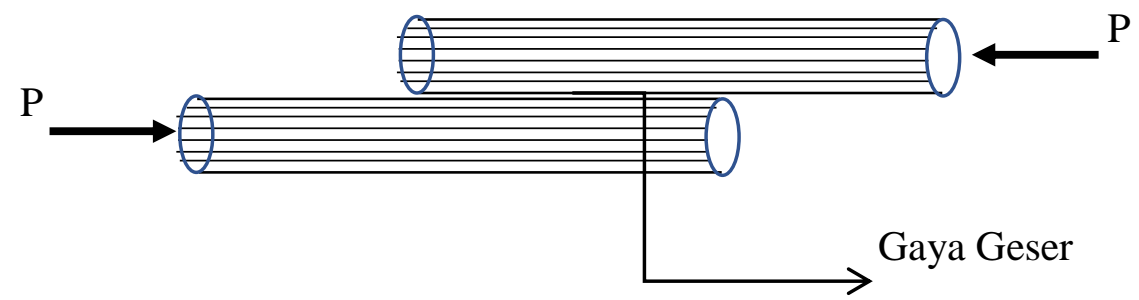

Sumber : Eratody (2017).

Gambar 3. Batang Bambu Menerima Gaya Geser.

\section{Kuat Lentur Bambu.}

Kuat lentur adalah kekuatan bambu untuk menahan gaya-gaya dari luar yang menyebabkan melengkungnya batang bambu. Bambu merupakan bahan yang elastis, maka lendutan yang terjadi sesuai kekuatan bahan menjadi agak tinggi (rata - rata 1/20). Tulangan dengan bambu dengan kulit memiliki sifat elastis yang lebih tinggi dibandingkan dengan tulangan bambu tanpa kulit, karena kulit lebih mampu menahan beban lentur dan hasil $\mathrm{P}$ Maks yang mampu ditahan lebih besar seperti pada Gambar 4 [24].

Kuat Lentur dapat dibedakan menjadi 2 (dua) macam, yaitu kuat lentur statik dan kuat lentur pukul. Kuat Lentur statik menunjukkan kekuatan bambu dalam menahan gaya yang mengenainya perlahan-lahan, sedangkan kuat lentur pukul adalah kekuatan bambu dalam menahan gaya yang mengenainya secara mendadak.

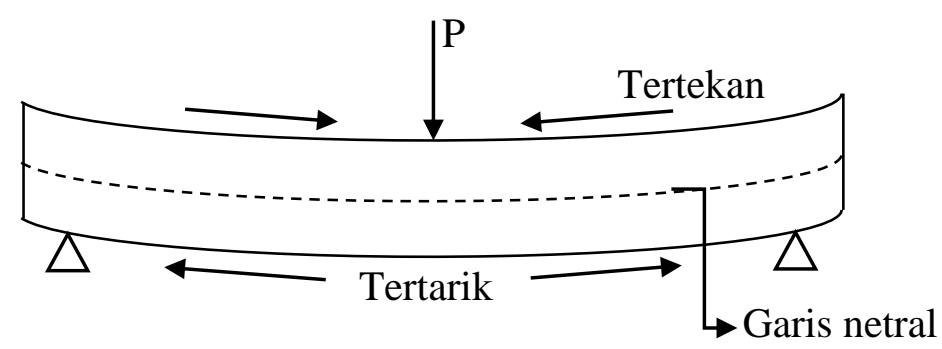

Sumber : Chamidah (2017).

Gambar 4. Batang Bambu Menerima Beban Lentur. 


\subsection{Pembebanan Struktur}

1. Beban Mati.

Dalam SNI 1727-2013 menyatakan beban mati adalah berat seluruh bahan konstruksi bangunan yang terpasang, termasuk dinding, lantai, atap, plafon, tangga, dinding partisi tetap, finishing, klading gedung dan komponen arsitektural dan structural lainnya serta peralatan layan terpasang lain termasuk berat keran [25]. Berat bahan dan konstruksi dalam pasal 3.1.3 dijelaskan bahwa menentukan beban mati untuk perancangan, harus digunakan berat bahan dan konstruksi yang sebenarnya, dengan ketentuan bahwa jika tidak ada informasi yang jelas, nilai yang harus digunakan adalah nilai yang disetujui oleh pihak yang berwenang. Berat peralatan layan tetap dalam pasal 3.1.3 dijelaskan bahwa dalam menentukan beban mati rencana, harus diperhitungkan berat perlatan layan yang digunakan dalam bangunan gedung.

\section{Beban Hidup.}

Beban hidup adalah beban yang diakibatkan oleh pengguna dan penghuni bangunan gedung atau struktur lain yang tidak termasuk beban konstruksi dan beban lingkungan, seperti beban angin, beban hujan, beban gempa, beban banjir, atau beban mati. Beban hidup atap adalah beban pada atap yan diakibatkan (1) pelaksanaan pemeliharaan oleh pekerja, peralatan, dan material dan (2) selama masa layan struktur yang diakibatkan oleh benda bergerak, seperti tanaman atau benda dekorasi kecil yang tidak berhubungan dengan penghunian.

\section{Beban Angin.}

Beban angin mengacu pada SNI 1727-2013 dimana bangunan gedung dan struktur lain, termasuk pada Sistem Penahan Beban Angin Utama (SPBAU) dan seluruh komponen termasuk klading gedung, harus dirancang dan dilaksanakan untuk menahan beban angin seperti yang ditetapkan menurut Pasal 26 sampai Pasal 31.

\section{Beban Hujan.}

Atap harus dirancang dapat menahan beban dari air hujan yang terkumpul apabila sistem drainase primer tertutup. Beban akan semakin merata apabila terjadi kenaikan air melampaui atas lubang drainase sekunder pada aliran rencananya.

\section{Beban Gempa.}

Dalam SNI 1726-2012 beban gempa merupakan beban yang terjadi pada gedung akibat adanya pergeseran tanah sehingga otomatis elemen gedung tersebut mengikuti pergerakan tersebut sehingga perlu adanya perhitungan untuk mengantisipasi terjadinya pergeseran tersebut yang dapat mengakibatkan keruntuhan pada bangunan [26]. 
6. Kombinasi Pembebanan

Kombinasi pembebanan sesuai dengan SNI 1727:2013 pada Pasal 2.3.2 kombinasi beban dan faktor beban. Kombinasi pembebanan yang digunakan dalam perencanaan struktur ini dapat dijabarkan sebagai berikut :
1) $1,4 \mathrm{D}$
11) $1,2 \mathrm{D}+1,0 \mathrm{~W}$ tekan $+\mathrm{L}+0,5 \mathrm{Lr}$
2) $1,2 \mathrm{D}+1,6 \mathrm{~L}+0,5 \mathrm{Lr}$
12) $1,2 \mathrm{D}+1,0$ Wtekan $+\mathrm{L}+\mathrm{R}$
3) $1,2 \mathrm{D}+1,6 \mathrm{~L}+0,5 \mathrm{R}$
13) $1,2 \mathrm{D}+1,0 \mathrm{~W}$ hisap $+\mathrm{L}+\mathrm{R}$
4) $1,2 \mathrm{D}+1,6 \mathrm{Lr}+\mathrm{L}$
14) $1,2 \mathrm{D}+\mathrm{Ex}+\mathrm{L}$
5) 1,2D + 1,6 $\mathrm{Lr}+0,5 \mathrm{~W}$ tekan
15) $1,2 \mathrm{D}+0.2 \mathrm{Ey}+\mathrm{L}$
6) $1,2 \mathrm{D}+1,6 \mathrm{Lr}+0,5$ Hisap
16) $0,9 \mathrm{D}+1,0 \mathrm{~W}$ tekan
7) $1,2 \mathrm{D}+1,6 \mathrm{R}+\mathrm{L}$
17) $0,9 \mathrm{D}+1,0 \mathrm{~W}$ hisap
8) 1,2D + 1,6 R+0,5 W tekan
18) $0,9 \mathrm{D}-0,2 \mathrm{Ey}$
9) 1,2D + 1,6 R + 0,5 W hisap
19) $0,9 \mathrm{D}-0,2 \mathrm{Ex}$

10) $1,2 \mathrm{D}+1,0 \mathrm{~W}$ hisap $+\mathrm{L}+0,5 \mathrm{Lr}$

Dimana :

$$
\begin{aligned}
\mathrm{D} & =\text { Beban Mati } \\
\mathrm{E} & =\text { Beban Gempa } \\
\mathrm{L} & =\text { Beban Hidup } \\
\mathrm{Lr} & =\text { Beban Hidup Atap }
\end{aligned}
$$

$$
\begin{aligned}
& \mathrm{R}=\text { Beban Hujan } \\
& \mathrm{S}=\text { Beban Salju } \\
& \mathrm{W}=\text { Beban Angin }
\end{aligned}
$$

Sumber : SNI 1727 : 2013 Pasal 2.3.2.

\section{Metode Penelitian}

\subsection{Diagram Alur Penelitian}

Alur pikir penelitian berdasarkan analisa teknis kekuatan konstruksi dan standardstandard yang berlaku di Indonesia seperti SNI 1726-2012 tahun 2012, tentang Tata Cara Perencanaan Ketahanan Gempa Untuk Struktur Bangunan Gedung dan Non Gedung dan SNI 1727-2013 tahun 2013, tentang Beban Minimum untuk Perancangan Bangunan Gedung dan Struktur Lain. Acuan rencana penelitian yang akan dilakukan menganut diagram alir pada

\section{Gambar 5.}




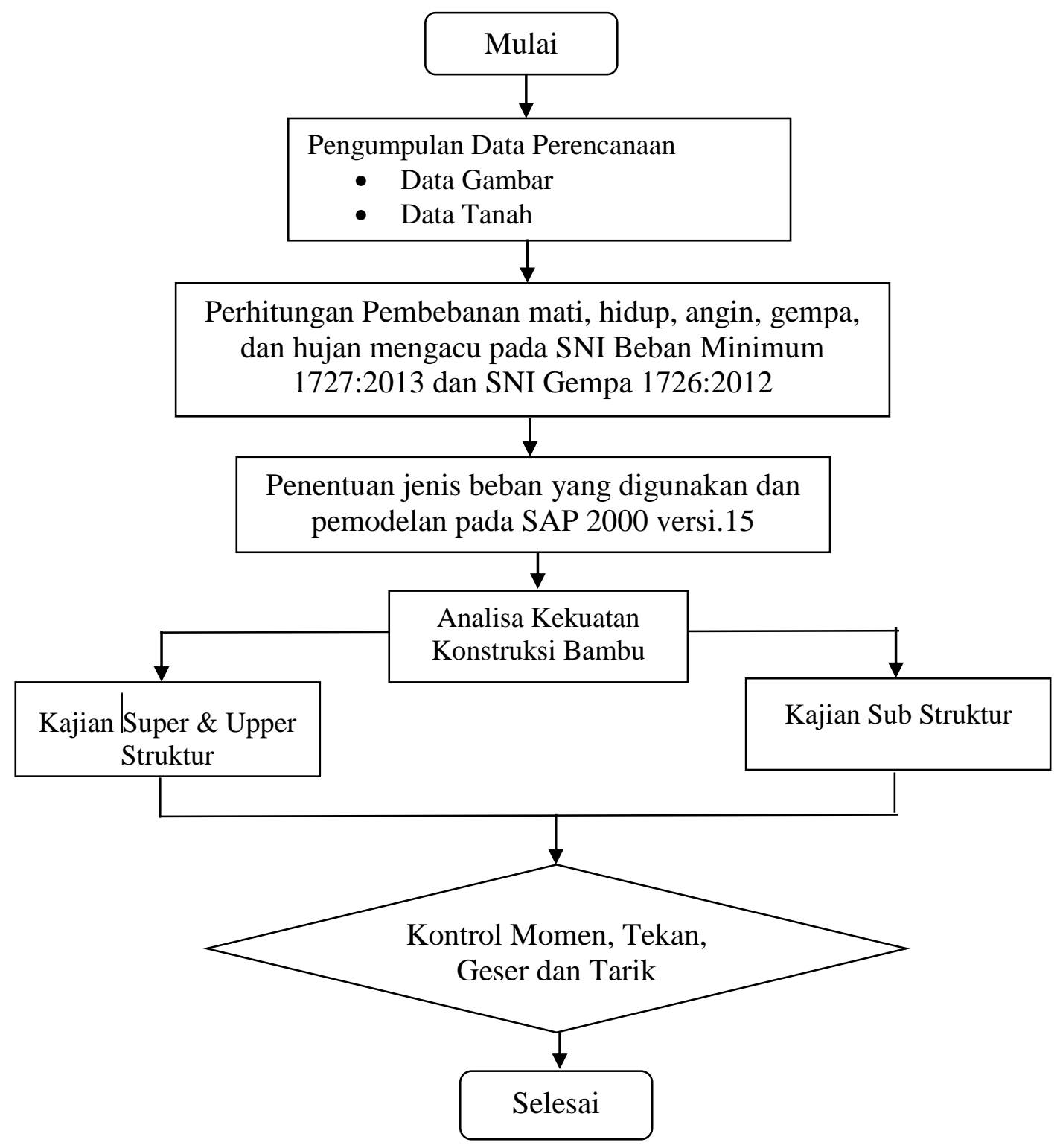

Gambar 5. Diagram Alir Skema Metode Penelitian.

\subsection{Lokasi}

Lokasi penelitian pada perencanaan Entry Building Green School Ubud di Dusun Tanggayuda, Desa Kedewataan, Kecamatan Ubud, Kabupaten Gianyar, Bali yang merupakan sebuah struktur bangunan gedung berlantai dua dengan seluruh konstruksi berbahan bambu.

\subsection{Metode Pengumpulan Data dan Analisa}

Metode yang digunakan dalam penelitian ini yaitu; metode survey melalui pengamatan site dimana konstruksi dibangun dan metode pustaka berdasarkan pengumpulan data-data sekunder bersumber dari buku, bacaan, dan internet yang terkait dengan penelitian ini. Data-data sekunder diambil juga dari jurnal-jurnal ilmiah yang terkait dalam penelitian green building. Analisa gaya-gaya dalam pada model struktur dibuat dalam tiga dimensi dengan bantuan Sofware Sap2000, versi 15 student [27]. 


\section{Hasil dan Pembahasan}

\subsection{Pemodelan Struktur Bambu}

Pemodelan struktur bambu menggunakan software SAP 2000 V. 15 dapat dilihat pada Gambar 6.

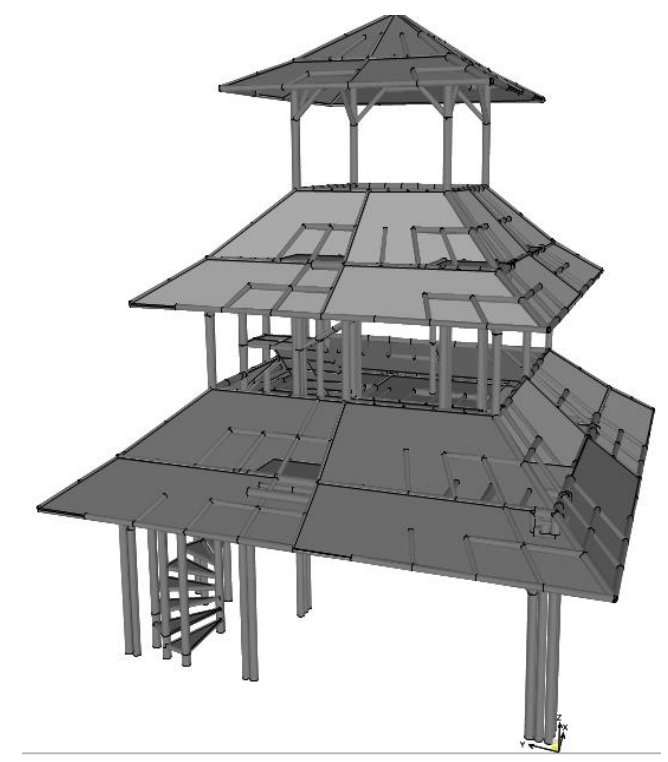

Sumber : SAP 2000 V. 15

Gambar 6. Pemodelan Struktur Bambu.

\subsection{Perhitungan Pembebanan}

Analisa terhadap perencanaan beban mati SDL untuk atap dapat dilakukan perhitungan dengan sebagai berikut :

1. Beban mati untuk atap terdiri dari berat genteng tanah liat sebesar $43,2 \mathrm{~kg} / \mathrm{m}^{2}$ menjadi $0,423792 \mathrm{~N} / \mathrm{mm}^{2}$.

2. Beban Mati Tambahan Untuk Ring Balok yaitu beban dinding kaca sebesar $20,56 \mathrm{~kg} / \mathrm{m}^{2}$.

3. Beban mati untuk plat lantai terdiri dari beban kabel sebesar $8,82 \mathrm{~kg} / \mathrm{m}$ berdasarkan brosur spesifikasi kabel.

Analisa terhadap perencanaan beban hidup dapat dilakukan dengan berdasar pada perhitungan berikut :

1. Beban hidup tangga :

a. beban tangga tetap $\quad=1,33 \mathrm{kN}=1330 \mathrm{~N}=135 \mathrm{~kg}$.

b. beban pegangan tangga sebesar $=1,11 \mathrm{kN}=1110 \mathrm{~N}=113 \mathrm{~kg}$.

2. Beban hidup perlantai ruangan untuk rumah tinggal pada lantai 2 dan 3 sebesar $195 \mathrm{~kg} / \mathrm{m}^{2}$.

3. Beban hidup pada atap pada saat pemeliharan pada atap berdasarkan SNI 1727-2013 sebesar $195 \mathrm{~kg} / \mathrm{m}^{2}$. 
Analisa beban air hujan berdasarkan SNI 1727-2013, diperoleh dari rumus :

$$
R=0,0098 .(d s+d h)
$$

Nilai $d s$ dan $d h$ diasumsikan, dapat diuraikan sebagai berikut :

$$
d s=10 \mathrm{~mm} \quad \mathrm{dh}=10 \mathrm{~mm}
$$

Maka dapat beban hujan dapat dihitung sebagai berikut :

$$
R=0,0098(10+10)=0,196 \mathrm{kN} / \mathrm{m}^{2}=0,196 \mathrm{~N} / \mathrm{mm}^{2} .
$$

Analisa beban angin untuk di rencanakan berdasarkan peraturan SNI 1727:2013, hasil analisa beban angin diperlihatkan pada Tabel 1. berikut :

Tabel 1. Rekapitulasi Beban Angin (W) Dengan Jarak Gording.

\begin{tabular}{cccc}
\hline $\begin{array}{c}\text { No } \\
\text { Gording }\end{array}$ & $\begin{array}{c}\text { Jarak Gording } \\
(\mathbf{m m})\end{array}$ & \multicolumn{2}{c}{ Beban Angin } \\
\hline 1 & 750 & $-0,0757$ & P-hisap (N/mm) \\
2 & 750 & $-0,0757$ & 0,0956 \\
3 & 1174 & $-0,1185$ & 0,0956 \\
4 & 1174 & $-0,1185$ & 0,1496 \\
\hline
\end{tabular}

Sumber : Rekapitulasi Beban Angin.

Data dari Tabel 1. merupakan rekapitulasi beban angin yang bekerja pada masing-masing gording dengan jarak gording yang berbeda.

Tabel 2. Rekapitulasi Beban Angin Pada Dinding.

\begin{tabular}{cccc}
\hline No & Tinggi Dinding & \multicolumn{2}{c}{ Beban Angin } \\
Batang & $(\mathbf{m m})$ & P-tekan (N/mm) & P-hisap (N/mm) \\
\hline 1 & 3600 & 0,2963 & $-0,1529$ \\
2 & 3600 & 0,2963 & $-0,1529$ \\
\hline
\end{tabular}

Sumber : Rekapitulasi Beban Angin Dinding.

Pada Tabel 2. menjelaskan bahwa beban angin yang bekerja pada kolom Analisa beban gempa menggunakan respon spectrum yang dianalisa dengan input koefisien factor keutaman gempa $(\mathrm{le})=1.0 \mathrm{Ss}$ pada wilayah Kabupaten Badung $=0.98 \mathrm{~S} 1$ pada wilayah Kabupaten Badung $=0.35$. Kelas Situs adalah tanah lunak (SE). Hasil analisa respon spektrum gempa ditunjukkan pada Gambar 7.

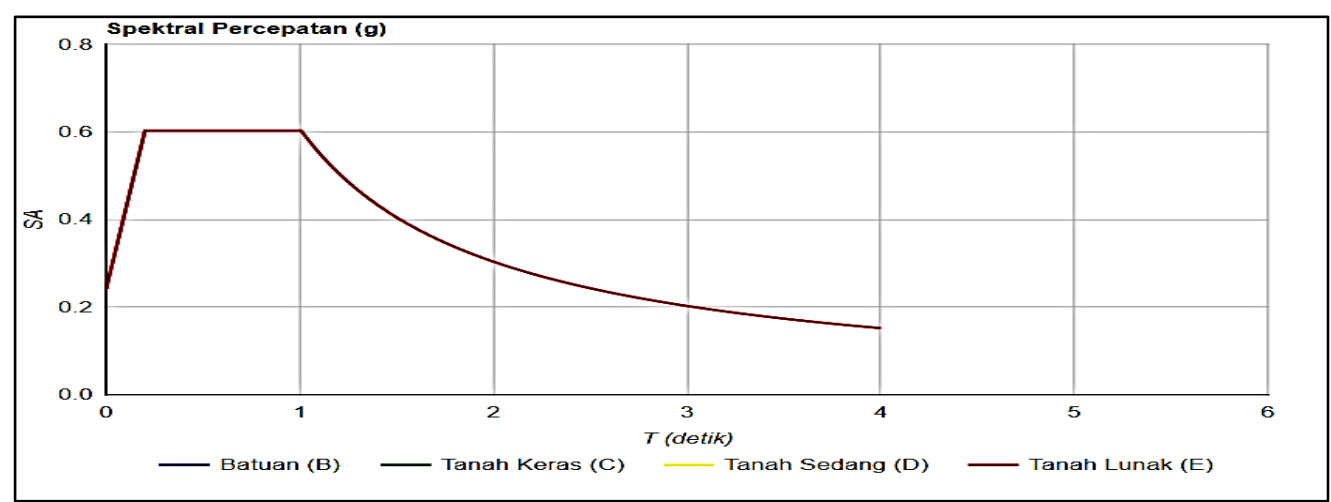

Gambar 7. Respon Spectrum. 


\subsection{Perhitungan Struktur}

Analisa dimensi bambu pada konstruksi dengan kontrol kekuatan ultimit terhadapa gaya aksial, geser dan momen lentur dapat disajikan pada Tabel 3. Tabel 4. dan Tabel 5.

1. Analisa Struktur Utama.

Tabel 3. Kontrol Pada Struktur Utama.

\begin{tabular}{cccc}
\hline Struktur & Dimensi $(\mathbf{m m})$ & Kontrol & Keterangan \\
\hline Kolom & Diameter 150 & $\mathrm{Pu}<\mathrm{Pn}$ & diterima \\
Balok & Diameter 151 & $\mathrm{Vu}<\mathrm{Vn}$ & diterima \\
Plat lantai & Diameter 80 & $\mathrm{Mu}<\mathrm{Mn}$ & diterima \\
\hline
\end{tabular}

Sumber : Analisis Data.

Keterangan : $\mathrm{Pu}=$ Tekan ultimit. $\mathrm{Vu}=$ Geser ultimit. $\quad \mathrm{Mn}=$ Momen Nominal. $\mathrm{Pn}=$ Tekan nominal. $\mathrm{Vn}=$ Geser nominal. $\mathrm{Mu}=$ Momen ultimit.

Pada Tabel 3. menjelaskan bahwa dimensi elemen struktur sudah sudah memenuhi syarat aman yaitu gaya yang bekerja lebih kecil dari kekuatan Nominalnya. Nilai lentur terkoreksi adalah dengan sebagai berikut :

$\mathrm{Mn}=103487,1534 \times 0,01=1196,22 \mathrm{Kg}$.

Kontrol Momen $=\mathrm{Mu} \quad<\mathrm{Mn}=763.39 \mathrm{Kg}<1196.22 \mathrm{Kg}$

OKE

2. Analisa Struktur Atas.

Tabel 4. Kontrol Pada Struktur Atas.

\begin{tabular}{cccc}
\hline Struktur & Dimensi $(\mathbf{m m})$ & Kontrol & Keterangan \\
\hline Usuk & Diameter 80 & $\mathrm{Pu}<\mathrm{Pn}$ & diterima \\
& & $\mathrm{Mu}<\mathrm{Mn}$ & diterima \\
Gording & Diameter 100 & $\mathrm{Vu}<\mathrm{Vn}$ & diterima \\
\hline
\end{tabular}

Sumber: Analisis Data.

Pada Tabel 4. dijelaskan bahwa dimensi elemen struktur sudah memenuhi syarat karena gaya bekerja lebih kecil dari kekuatan Nominalnya dengan koreksi sebagai berikut :

$M^{\prime}=232071,42 \times 0,007=1657,802 \mathrm{~kg}$.

Kontrol momen $\mathrm{Mu}<\mathrm{Mn}=146,14 \mathrm{~kg}<1657,8 \mathrm{~kg}$

OKE.

3. Analisa Struktur Bawah

Analisa kapasitas dukung tanah dengan Analisa beban tidak terfaktor pada model struktur berdasarkan data tanah pada Tabel 5.

Tabel 5. Data Tanah Dan Analisis Kapasitas Ijin Tanah.

\begin{tabular}{cccccc}
\hline $\begin{array}{c}\mathrm{Kdlm} \\
(\mathrm{m})\end{array}$ & $\left.\mathrm{Q}^{\circ}\right)$ & $\lambda \mathrm{b}\left(\mathrm{t} / \mathrm{m}^{3}\right)$ & Qult $\left(\mathrm{t} / \mathrm{m}^{2}\right)$ & Qult $\left(\mathrm{kg} / \mathrm{m}^{2}\right)$ & Qijin $\left(\mathrm{kg} / \mathrm{m}^{2}\right)$ \\
\hline 1 & 2,6 & 1,63 & 29,8032 & 2,98032 & 0,993 \\
3 & 32,3 & 1,97 & 244,8 & 24,48 & 8,16 \\
\hline
\end{tabular}

Sumber : Analisis Data. 
Menghitung kapasitas dukung batas :

$$
\mathrm{Q}=\mathrm{F} / \mathrm{A} \text {. }
$$

Dimana $=F=2697,66 \mathrm{~kg} . \quad \mathrm{A}=1200 \times 1200 \mathrm{~cm}=14400 \mathrm{~cm}^{2}$.

Maka $\mathrm{Q}=0,19 \mathrm{~kg} / \mathrm{cm}^{2}$.

Kontrol Kapasitas Dukung $=\mathrm{Q}<$ Qijin $=0,19<0,993$.

OKE.

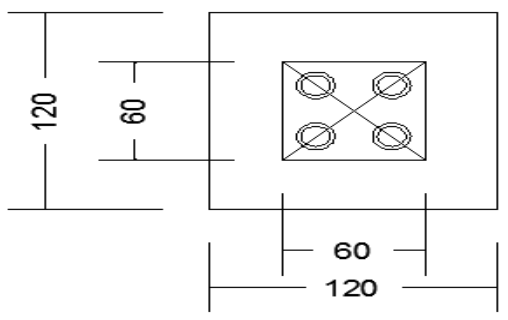

Den ah Pondasi

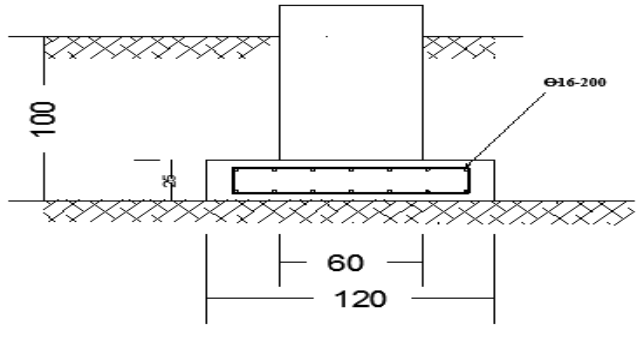

Potongan

Sumber : Analisa Fondasi Telapak Untuk 4 Bambu.

Gambar 8. Fondasi Untuk 4 Bambu.

Analisa untuk fondasi lebih dari 1 kolom diperoleh nilai Mn sebesar 6689,653 kgm.

Kontrol $=\mathrm{Mu}<\varnothing \mathrm{Mn}=101.162<5351,72$.

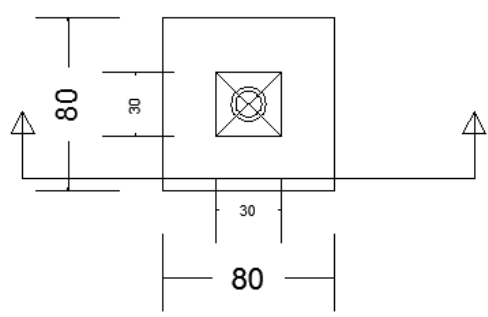

Denah Pondasi

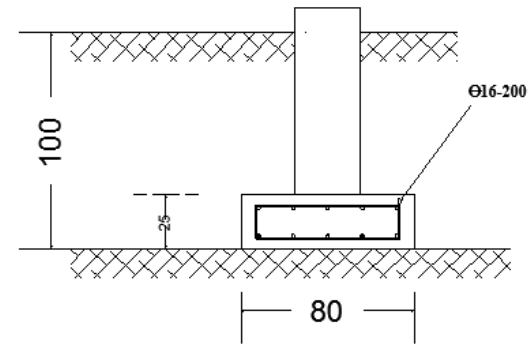

Potongan

Sumber : Analisa fondasi telapak untuk 1 bambu.

Gambar 9. Fondasi Untuk 1 Bambu.

Sehingga nilai Mn 44597686,27 Nmm menjadi 4459,769 kgm

Kontrol $=\mathrm{Mu}<\varnothing \mathrm{Mn}=105,377<4459,769$

OKE.

Tabel 5. Kontrol Pada Struktur Bawah

\begin{tabular}{cclc}
\hline Struktur & Dimensi $(\mathbf{m m})$ & Kontrol & Keterangan \\
\hline Fondasi Telapak & $1200 \times 1200$ & $\mathrm{Vu}<\varnothing^{\prime} \mathrm{V}^{\prime}$ & $\begin{array}{c}\text { diterima } \\
\text { diterima }\end{array}$ \\
\hline
\end{tabular}

Sumber : Analisis Data.

Fondasi telapak direkomendasikan berdasarkan Tabel 5, dimana Analisa daya dukung tanah telah dilakukan dengan beban tidak terfaktor selanjutnya fondasi telapak berbahan beton bertulang dilakukan dengan Analisa beban terfaktor. 


\section{Kesimpulan dan Saran}

\subsection{Kesimpulan}

Berdasarkan hasil Analisa kekuatan konstruksi Entry Building Green School Ubud dapat disimpulkan dengan sebagai berikut :

1. Analisa struktur bangunan atas didapat dimensi kuda-kuda dengan bahan bambu dengan dia $120 \mathrm{~mm}$, usuk dengan dia $80 \mathrm{~mm}$ dan gording dimensi bambu $120 \mathrm{~mm}$ telah memenuhi syarat aman.

2. Analisa struktur bangunan utama pada kolom bambu berdimensi D $150 \mathrm{~mm}$, balok D 150 $\mathrm{mm}$ dan plat dengan $\mathrm{D} 80 \mathrm{~mm}$ telah memenuhi syarat aman.

3. Analisa struktur bangunan bawah atau pondasi menggunakan dimensi $0,8 \mathrm{~m} \times 0,8 \mathrm{~m}$ dan 1,2 $\mathrm{m} \times 1,2 \mathrm{~m}$ untuk perencanaan angkur menggunakan diemensi baut 12,7 $\mathrm{mm}$ dengan jumlah baut yaitu sebanyak 2 buah sudah memenuhi syarat aman.

4. Penggunaan material bambu memberikan nilai estetika serta dimensi frame kecil karena berat sendiri yang lebih ringan daripada menggunakan material baja ataupun beton karena memperlihatkan bangunan menjadi masiv.

\subsection{Saran}

Dalam penerapan struktur bambu, bambu yang akan digunakan untuk konstrukasi harus melalui proses pengawetan terlebih dahulu agar bambu tidak terkena hama dan jamur. Sambungan pada bambu tidak dianjurkan menggunakan paku baja sebagai alat sambungan baut, sebab paku dapat membelah dan merusak bambu, dapat digunakan paku apabila bambu dibor terlebih dahulu. Sambungan yang cocok dengan bambu adalah diikat dengan tali 


\section{Daftar Pustaka}

[1] I. G. L. B. Eratodi and A. Awaludin, "Bending Capacity of Non-prismatic LVL Beams Paraserianthes Falcataria," Procedia Eng., vol. 171, pp. 1362-1369, 2017.

[2] I. W. Ariyana and I. N. Sinarta, "Kapasitas Dukung Fondasi Diatas Tanah Timbunan Sampah Sebagai Usaha Mitigasi Bencana," in Senats3 (Seminar Nasional Teknik Sipil), 2019, p. GT-25-35.

[3] I. N. Sinarta and I. W. A. Basoka, "Keruntuhan Dinding Penahan Tanah dan Mitigasi Lereng di Dusun Bantas, Desa Songan B, Kecamatan Kintamani," J. Manaj. Aset Infrastruktur Fasilitas, vol. 3, no. 0, pp. 23-32, 2019.

[4] A. Haris, PENGUJIAN SIFAT FISIS DAN MEKANIS BULUH BAMBU SEBAGAI BAHAN KONSTRUKSI MENGGUNAKAN ISO 22157-1: 2004. Institut Pertanian Bogor, 2008.

[5] A. I. Candra, E. Gardjito, Y. Cahyo, and G. A. Prasetyo, "Pemanfaatan Limbah Puntung Rokok Filter Sebagai Bahan Campuran Beton Ringan Berpori," UKaRsT, vol. 3, no. 1, p. 82, 2019.

[6] I. N. Sinarta and I. W. Ariyana Basoka, "Safety factor analysis of landslides hazard as a result of rain condition infiltration on Buyan-Beratan Ancient Mountain Safety factor analysis of landslides hazard as a result of rain condition infiltration on Buyan-Beratan Ancient Mountain,” J. Phys. Conf. Ser., vol. 1402, no. 2, 2019.

[7] A. A. Saputra, C. Engineering, and S. Program, "Perencanaan struktur baja pada konstruksi empat lantai pada hotel jaya baya (," pp. 67-73.

[8] A. I. Candra, "Pada Pembangunan Gedung Mini Hospital Universitas Kadiri," Ukarst, vol. 1, no. 1, pp. 63-70, 2017.

[9] A. Maurina, "Penggunaan bambu pada struktur rangka dan struktur permukaan aktif pada bangunan organik dengan bentuk atap bergelombang," no. April, pp. 21-31, 2014.

[10] Handayani, "PENGUJIAN SIFAT MEKANIK BAMBU (METODE PENGAWETAN DENGAN BORAKS)," J. Tek. Sipil dan Perenc., vol. 9, pp. 1-12, 2007.

[11] S. Kumar and P. Dobriyal, "Preservative Treatment of Bamboo for Structural Uses," 1998.

[12] I. N. Sinarta, A. Rifa'i, T. F. Fathani, and W. Wilopo, "Indeks Ancaman Gerakan Tanah Dengan Metode Analythical Hierarchy Process (AHP) Untuk Penataan Infrastruktur Kepariwisataan Di Kawasan Geopark Gunung Batur, Kabupaten Bangli, Bali," Semin. Nas. KonsepSi\#2 (Konsep dan Implementasi 2), vol. 1, pp. 110-120, 2016.

[13] I. N. Sinarta and I. W. Ariyana Basoka, "The potential of liquefaction disasters based on the geological, CPT, and borehole data at southern Bali Island," J. Appl. Eng. Sci., vol. 17, no. 4, pp. 535-540, 2019.

[14] H. Frick, Ilmu Konstruksi Bangunan Bambu, 1st ed. Yogyakarta: Kanisius, 2004. 
[15] I. N. Sinarta, A. Rifa'i, T. F. Fathani, and W. Wilopo, "Slope Stability Assessment Using Trigger Parameters and SINMAP Methods on Tamblingan-Buyan Ancient Mountain Area in Buleleng Regency, Bali," Geosciences, vol. 7, no. 4, p. 110, 2017.

[16] N. K. A. Artiningsih, "Pemanfaatan Bambu Pada Konstruksi Bangunan Berdampak Positip Bagi Lingkungan," Metana - Media Komun. Rekayasa Proses dan Teknol. Tepat Guna, vol. 8, no. 01, pp. 1-9, 2012.

[17] A. I. Candra and E. Siswanto, "REKAYASA JOB MIX BETON RINGAN MENGGUNAKAN HYDROTON DAN MASTER EASE 5010,” J. CIVILA, vol. 3, no. 2, p. 162, Oct. 2018.

[18] Morisco, Bambu sebagai Bahan Rekayasa, Pidato Pengukuhan Jabatan Lektor Kepala Madya Fakultas Teknik UGM: Yogyakarta, 1st ed. Yogyakarta, 1996.

[19] Morisco, Rekayasa Bambu. Yogyakarta: Nafiri Offset, 1999.

[20] I. W. Sugiartha and A. Rofaida, "Kuat Tarik Sambungan Bambu Celah Berpengisi Dengan Alat Sambung Baut Pada Berbagai Variasi Jarak Ujung," JST (Jurnal Sains Ter., vol. 4, no. 1, pp. 17-22, 2018.

[21] A. D. Krisna, D. S. Winarto, S. T. Mt, A. Ridwan, and S. E. S. T. Mt, "Penelitian Uji Kuat Tekan Beton Dengan Memanfaatkan Limbah Ampas Tebu Dan Zat Additif Sikacim Bonding Adhesive," jurmateks, vol. 2, no. 1, pp. 1-11, 2019.

[22] I. G. L. B. Eratodi, STRUKTUR DAN REKAYASA BAMBU, 1st ed. Denpasar: Universitas Pendidikan Nasional, 2017.

[23] M. A. Anshori, "PENELITIAN UJI KUAT TEKAN BETON DENGAN MEMANFAATKAN AIR LIMBAH TETES TEBU DAN ZAT ADDITIVE CONCRETE," jurmateks, vol. 2, no. 1, pp. 11-22, 2019.

[24] L. L. Chamidah, R. M. Simatupang, and A. Pujiraharjo, "PERBANDINGAN KAPASITAS KUAT LENTUR PADA BALOK TULANGAN BAMBU PILIN DENGAN KULIT DAN TANPA KULIT (Comparasion of the Flexural Strength Capacity of the Knitted Bamboo Reinforcement Beam with and without Skin)," J. Mhs. JurusanTeknik Sipil Fak. Tek. Univ. Brawijaya, vol. 1, no. 3, 2017.

[25] SNI and 1727-2013, Beban minimum untuk perancangan bangunan gedung dan struktur lain. 2013.

[26] SNI 1726-2012, Tata cara perencanaan ketahanan gempa untuk struktur bangunan gedung dan non gedung, 1st ed., vol. 15, no. 3. Jakarta: Bandung: Badan Standardisasi Indonesia, 2012.

[27] I. Satyarno, P. Nawangalam, and R. I. Pratomo P, Belajar Sap 2000, 2nd ed. Yogyakarta: Zamil Publishing, 2012. 